\title{
素 描
}

\section{ごみ問題発生の背景}

栗原四郎*

日本の高度経済成長の進展とともに，産業から，家庭から排出されるごみの 量は超高度增大の一途をたどり, 廃楽物処理不能寸前の事態になっている。 このような状態になった大きな原因は，物をつくるという積極的なことと異な りごみを含むすべての廃棄物を処理することはとかく消極的になりがちで， これが今日巨大な量のごみの発生となり, その解決策が後手後手となってしま った結果である。もはや私たちは自分の出したごみで，自家中毒に陷りそらに なっている。なんらかの抜本的な方策の樹立をできるたけするやかに確立しな いと，真の自家中毒死に至るであろう。ここにごみ間題発生の背景について私 なりに考察をしてみた。

まず第 1 にごみと住民の関係である。ごみは人間の生活による残留物で，か つ不要物である。このごみを生活圈からできるだけすみやかに排除するのがご み処理作業である。それゆ光, 市町村も住民も生活環境からごるの姿が完全に なくなることが，健全なるごみ処理作業であると考劣，かつ信じていたのであ る。事実この姿は，五，六年前まではよかった。それゆえ国の方針もごみ処理 体系は収集, 運搬, 処理という3 部門の一連作業といら考えであり, 市町村も この方針を基本にして事業を実施している。そ扎ゆ市市町村のごみ処理作業計 画は「ごみと名のつくものは出しなさい。処理はしてあげます」といらことで 掌にあたっているのである。住民としては定められた日にごみを出せば生活環 境は清潔に保持されてきたのである。

このような処理態勢はごみの増量を促し，大量消費時代の到来となり，これ により利潤を得た企業者にとって，この方式はむことにありがたい存在であっ たに違いない。また住民に対してはこの方法はあまりにも過保護であったた め, 自然とごみ排出者の自覚が久けてきた。ごみ処理の過程中には必ず排出者 が存在するといらことである。ごみ処理は市町村のみでなく, ごみ排出者自身 もその一翼をになっていることである。ごみ処理は排出者の貯蔵よりはじま り, 収集, 運搬という生活環境よりの排除となり, 破䂗, 圧縮, 焼却などの処 理を経て処分されるものである。収集から処理までの過程が衛生的に, 経済的 に実施できるか否かは, かかって排出者のごみ貯蔵の良否にかかっている。こ の收集されたごみは焼却か埋立によって処理, 処分されなければならない。こ の処理場は東京都のような過密都市では，ご排出者の周辺に求めざるをえな いことになる。都市の住民は一様に排除による快適な生活環境が得られるが， 処理場周辺の住民は逆に「押しつけられる」という被害者感情が生ずる。この 感情が処理場設置反対として現われ，今日のごみ問題発生の導火線となって

* Shiro KURIHARA 東京都清掃研究所（124 東京都葛飾区小管町 1-4-1）所長 
いる。

次に問題点となった原因は処理技術の立遅れをあげることができる。これに は次の三つの事柄が考兄られる。その一つはごみの環境污染速度の遅いことで ある。し尿や煙のようにごみは排出と同時に環境を污染しない。そのため一時 処理が遅れてもよかららといら考穴が処理技術の立遅れをもたらした。これが 「たかがごみ」といら観念を排出者も市町村も持っていたことは否定できない。 道路や河川への不法投棄や市䧓村のごみの埋立処理方式への依存度の高いのが 顕著な例である。埋立方式は土䇾中のバクテリアの働きによる高度の生物化学 的操作を必要とするが, 今の埋立は不法投菜に近い状態で, 衛生埋立とはほど 遠いのも「たかがごみ」の観念からくるものである。その二つは質, 量の把握 の困難性があげられる。し尿は 1 人 1 日あたり約 $1.2 l$ の排出量で, これに将 来推定人口をかければ概略の処理施設の規模は算出できる。また質に括いても 全国的には有意の差は認められないので，一定の規格による処理施設は可能で 下水道処理がよい例である。ところが，ごみは「ごみとは社会通念上，占有者 が生活環境に支障ありと認めたときに，占有の意志を破睡して投棄した固体廃

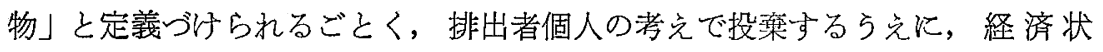
態，季節，天候，はては個人所得をで影響する。さらに「消費は美徳」，「使い 捨て」の思想はごみの質，量をより変化させている。このような性状を有する ごみ処理に対する研究は複雑かつ困難で, し尿処理技術に比較して数段立遅れ ている。三つめはごみの発生場所に和ける定着性をあげることがだきる。ごみ の場所的移動には必ず人手によらなければならないという宿命を有している。 ごみをはじめ固体廃物は発生場所に定着性を有している。この定着性を有する ごみの移動は，好むと好まざるにかかわらず，人為的操作を必要とする。この 輸送は現在自動運搬しかない。ごみの移動がもし下水道管のようにごみ道管と もいらべき移動方法であるならば，江東区の事態も起こらなかったのではなか ろらか。

要するに以上のように考えてみると，今日ごみ問題は起こるべくして起きた 感じが深い。ごみ問題解決には市町村当局ばかりでなく，国民一人一人がごみ に対する考方方を改めなくてはならない。ごみを永久にごみと考㝋ている限り (ごみの原料化)「たかがごみ」という観念をもつ限り，被害者であると同時に 加害者であるといら観念が漫透しない限り, 恩恵感情と被害者感情が相殺され ない限り，ごみ問題は永久に消隇することはありえないのではなかららか。 